\title{
Natural gas hydrate promotion capabilities of toluene sulfonic acid isomers
}

\author{
Azad Jarrahian ${ }^{1}$, Ehsan Heidaryan ${ }^{* 2}$ \\ ${ }^{1}$ Sharif University of Technology, Department of Chemical and Petroleum Engineering, Tehran, Iran \\ ${ }^{2}$ Shiraz University, School of Chemical and Petroleum Engineering, Shiraz, Iran \\ "Corresponding author: e-mail: heidaryan@engineer.com
}

\begin{abstract}
The purpose of this study was to investigate the natural gas hydrate promotion capabilities of the hydrotrope Toluene Sulfonic Acid (TSA) isomers as an additive. The capabilities of TSA isomers were measured with different concentrations. The optimum additive concentration for hydrate formation was determined for the given pressure, temperature, mixing condition, and cooling time. The natural gas hydrate promotability of para-TSA was found to be $20 \%$ and $35 \%$ more than meta-TSA and ortho-TSA respectively at the optimum concentration. Beyond the optimum TSA concentration, the hydrate formation declined as the ice formation reduced the overall gas-to-water volume ratio in the hydrates
\end{abstract}

Keywords: natural gas hydrate, hydrotrope, toluene sulfonic acid.

\section{INTRODUCTION}

One of the research interests on natural gas in a commercial perspective is using of hydrates as a media for storage and transport. The idea of using hydrates as a gas storage medium existed since early $1940 \mathrm{~s}^{1}$ when its self-preservation, which allows hydrate to remain metastable at atmospheric pressure and a few degrees below the ice point. However, recently, natural gas hydrate has drawn much attention as a new means for natural gas storage and as an alternate for safe transport ${ }^{2}$.

Hydrates have unique gas storage properties, as they can contain 180 volumes (standard temperature, pressure) of natural gas per volume of hydrate ${ }^{3}$ and could be stored at $258 \mathrm{~K}$ under atmospheric pressure for 15 days, retaining almost all the gas ${ }^{4}$. Storage of natural gas in the form of clathrate hydrates is of interest since hydrates can be produced under moderate conditions and can be stored at a typical temperature of $273 \mathrm{~K}$ under reasonable pressures of $1-2 \mathrm{MPa}^{5,6}$. In contrast, the conditions for conventional natural gas storage technologies are extreme, for example, the pressure of $20 \mathrm{MPa}$ for compressed natural gas and temperature of $113 \mathrm{~K}$ for liquefied natural gas ${ }^{7}$. As well as in transport, it showed a big cost saving of $24 \%$ for the transport of natural gas in hydrates compared to liquefied natural gas ${ }^{8}$.

Not only, storage capacity appealing for industrial use of natural gas, as well as the process is appealing for safety reasons, slow release of natural gas from hydrates in case of storage tank rupture; flammable gases essentially encased in ice and relatively low storage pressures.

However, industrial applications of hydrate storage processes have been hindered by three problems, which affect the ability and economy of process scale up: slow formation rates, separating and packing hydrate particles for storage, and unreacted interstitial water as a large percentage of the hydrate mass.

Hydrates do not form immediately when water and natural gas are in contact at hydrate forming conditions. This process is occurring in three consecutive steps. Labile clusters form immediately (labile clusters) on dissolution of gas in water; they agglomerate by sharing faces, thus increasing disorder (agglomeration). The size of the cluster agglomerate reaches a critical value, growth begins (primary nucleation and growth).
Gas dissolution, formation of nuclei and growth of the new nucleus are mainly affected by pressure and temperature conditions of the system. In addition, agitating water increases the water-gas interfacial area and improves hydrate formation. Energy costs from stirring increase as slurry thickens. In fact, thickening slurry of the stirred may limit the hydrate mass in the water to as low as $5 \%{ }^{10,11}$.

The surfactants molecules help minimize mass transfer and kinetic difficulties during hydrate formation ${ }^{12}$. This mechanism is applicable not only through surfactants but with ultrasonic waves ${ }^{13}$. When surfactants are added to a hydrate forming, the induction time (the period necessary for the appearance of the very first hydrate cluster of supernucleus size) required for hydrate formation decreases, and the hydrate formation rate increases ${ }^{14,15}$. During the last two decades, several studies have been reported showing a significantly increased hydrate formation rate with adding surfactant molecules ${ }^{16-19}$. The economics of synthetic natural gas hydrates as storage and transport medium critically depends on the gas volume stored per volume of hydrates. The purpose of the current study is to use a fundamental procedure to determine the peak concentration of the hydrotrope, Toluene Sulfonic Acid (TSA) isomers, for maximizing hydrate formation.

\section{EXPERIMENTAL METHOD}

\section{Materials Used}

The experiment materials in this work are listed in Table 1 . The additives were weighted with the accuracy of $\pm 0.01 \mathrm{~g}$ on an electronic balance. Distilled water was used in all experiments. The composition of the natural gas is presented in Table 2.

Table 1. Materials used in this study

\begin{tabular}{|l|l|c|}
\hline Component & Purity [\%] & Supplier \\
\hline para-TSA & 98.5 & Sigma-Aldrich \\
\hline meta-TAS & 98 & Merck \\
\hline ortho-TAS & 98 & Merck \\
\hline Water & Distilled & - \\
\hline
\end{tabular}

\section{Apparatus}

Stainless steel sulfur combustion reactor with capacity of $424 \mathrm{~cm}^{3}$ and maximum pressure of $20 \mathrm{MPa}$ was used 
Table 2. Composition of the natural gas mixture used in this study

\begin{tabular}{|l|c|}
\hline Component & Mol [\%] \\
\hline Methane & 71.5 \\
\hline Ethane & 11.0 \\
\hline Propane & 6.5 \\
\hline n-Butane & 1.9 \\
\hline iso-Butane & 0.9 \\
\hline n-Pentane & 0.4 \\
\hline iso-Pentane & 0.4 \\
\hline Carbon Dioxide & 4.0 \\
\hline Nitrogen & 1.8 \\
\hline Hydrogen Sulfide & 1.6 \\
\hline Total & 100 \\
\hline
\end{tabular}

for this experiment ${ }^{20}$. The cell was $6 \mathrm{~cm}$ in internal diameter and $15 \mathrm{~cm}$ in height. Through a branched fitting a resistance temperature detector probe (RTD), placed on the top of the cell; allowing temperature measurement during the process. As well as a pressure transducer calibrated from 0-11 MPa was mounted on the branch fitting. The pressure relief valve was set to relieve at 11 $\mathrm{MPa}$ and was fitted on one end of the branch fitting.
Two internal diameter viewing tubes extended into the cell through two Female Nominal Pipe Thread (FNPT) ports. The short one allowed light input from a $150 \mathrm{~W}$ source sent by a fiber optics light guide; the long one enabled observing hydrate formation through a camera probe inserted in it. Both viewing tubes were sealed at one end with transparent sapphire windows pressure checked at $11 \mathrm{MPa}$.

The cell contents was mixed with a magnetic stirrer $(9.5 \times 38 \mathrm{~mm}$ magnetic stir bar) at the speed of 250 rpm. A cooling bath which could able to maintain the temperature with the accuracy of $\pm 0.01 \mathrm{~K}$ from the set point was also used. A gas booster system was used to compress the gases to the pressures required in this research $^{\mathbf{2 1}, \mathbf{2 2}}$. The RTDs, pressure transducers and gas volume meter were all connected to a data acquisition system, which was inserted into the expansion slots of a computer. The schematic diagram of the experimental set-up is shown in Figure 1.
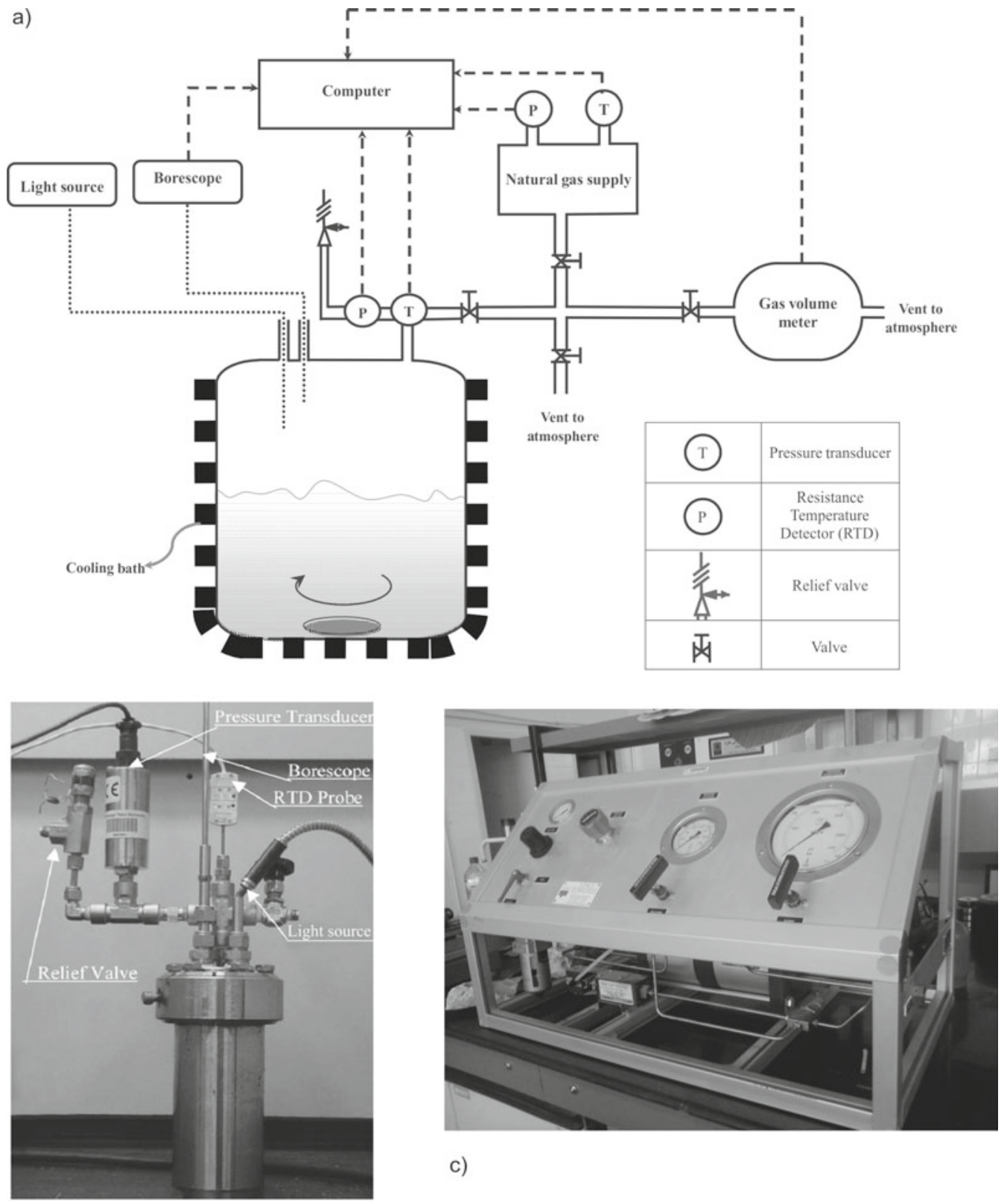

c)

b)

Figure 1. a) Schematic diagram of the experimental apparatus b) Hydrate formation reactor vessel c) Gas pressure booster 

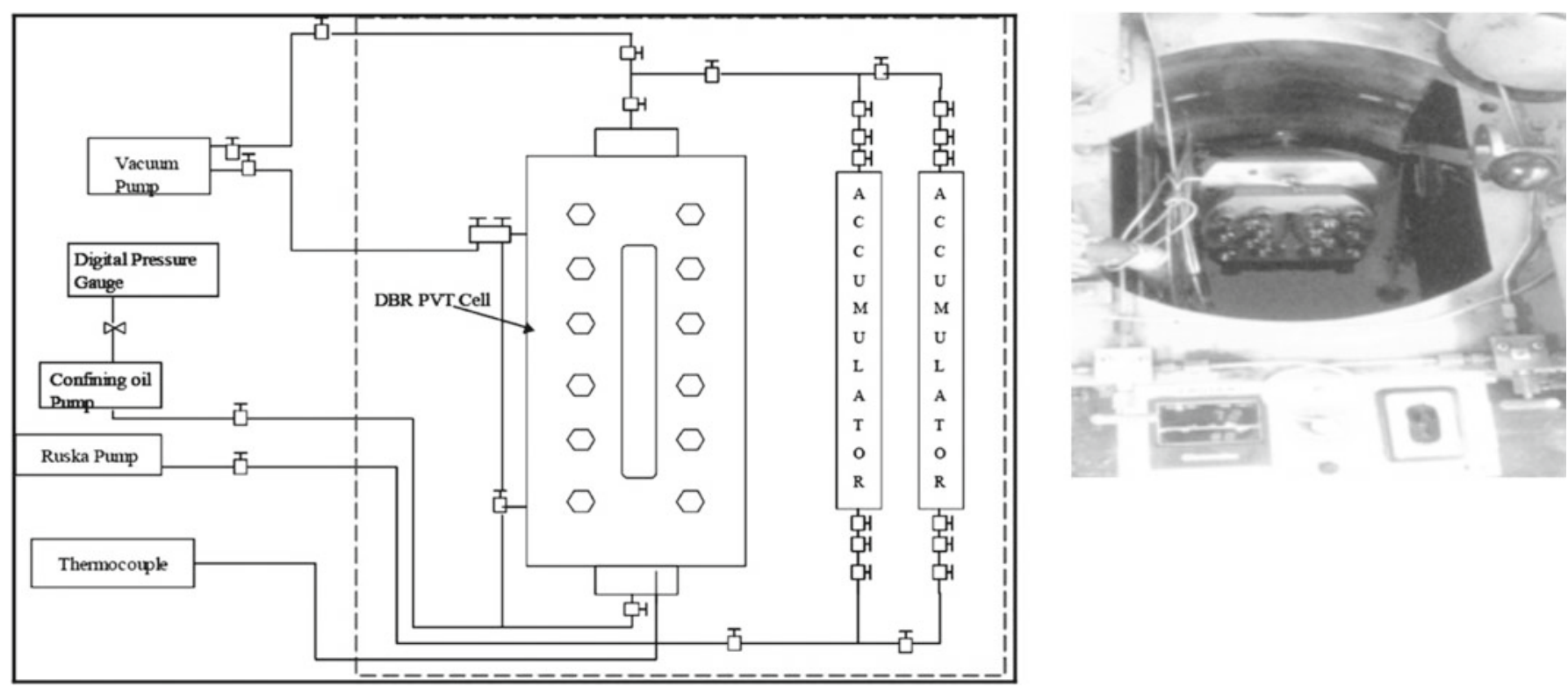

Figure 2. A schematic of experimental setup for PVT and hydrate formation experiments

\section{Experimental Procedure}

Natural gas dew points and hydrate formation curve

A High-Pressure High-Temperature (HPHT) the visual laboratory cell (Figure 2$)^{\mathbf{2 3}}$ has been used to study the natural gas properties and the condition in which hydrates form. The HPHT cell has a $100 \mathrm{MPa}$ maximum working pressure, from 266 to $422 \mathrm{~K}$ working temperature and a $100 \mathrm{~cm}^{3}$ total volume. The cell also has a transparent glass cylinder which allows the fluid to be observed. After dew point pressure tests, to perform the hydrate experiments, the high-pressure visual cell was thoroughly cleaned and evacuated before being filled with the sample. Then, the hydrocarbon fluid was introduced to the cell and meanwhile, to fix the pressure and temperature, the piston's position moved accordingly. A high pressure pump was then used to inject water into the cell. The visual capacity of the cell, allows the correct determination of the hydrate formations' conditions. During the experiment, the pressure was kept constant and the temperature was cooled down to pinpoint the conditions in which hydrate form with an acceptable accuracy.

\section{Hydrate promotion capability}

The liquid mixture (approximately $200 \mathrm{~cm}^{3}$ in each experiment of water + TSA isomers) was introduced in the cell and placed into a temperature bath set, about $5 \mathrm{~K}$ above the expected three-phase $\left(\mathrm{H}-\mathrm{L}_{\mathrm{w}}-\mathrm{V}\right)$ equilibrium temperature.

Air was removed from the cell by a vacuum pump and natural gas purging ${ }^{24}$. Subsequently, the cylinder was pressurized to the test pressure. The temperature was then gradually decreased and enough time was given to the system to reach equilibrium condition ${ }^{25}$.

The cylinder was then depressurized to ambient pressure, one at a time, to remove the excess gas, formed during the process. The depressurizing procedure was carried out at maximum speed to minimize the hydrate dissociation and also to ensure the removal of the excess gas. Dissociating procedure was done using the isochoric temperature cycle method ${ }^{\mathbf{2 6}}$.
The cylinder temperature was gradually increased and set at $300 \mathrm{~K}$ for $10 \mathrm{~min}$ being connected to the gas volume meter while the gas pressure was just above atmospheric pressure. The gas released from the hydrates displaced the gas from the cylinder. Inaccuracies in gas volume measurement, due to the dissolved gas in water, were ignored during the measurements of gas volume ${ }^{27}$. The gaseous volume is measured from the meter considered as the standard gas volume.

\section{RESULTS AND DISCUSSION}

Figure 3 shows the experimental dew points and the hydrate formation curve as well as predicted phase envelop, critical point (results of GERG-2008 ${ }^{28}$ ), and the pure water hydrate formation (result of Ameripour and Barrufet correlation ${ }^{\mathbf{2 9}}$ ) for the natural gas of given composition and test points.

Instead of using the method of volume of gas stored in a unit volume of hydrate which was proposed by Makogon ${ }^{30}$, hydrate capacity was measured by the gas-to-water volume ratio in the formed hydrate ${ }^{\mathbf{3 1}}$ which

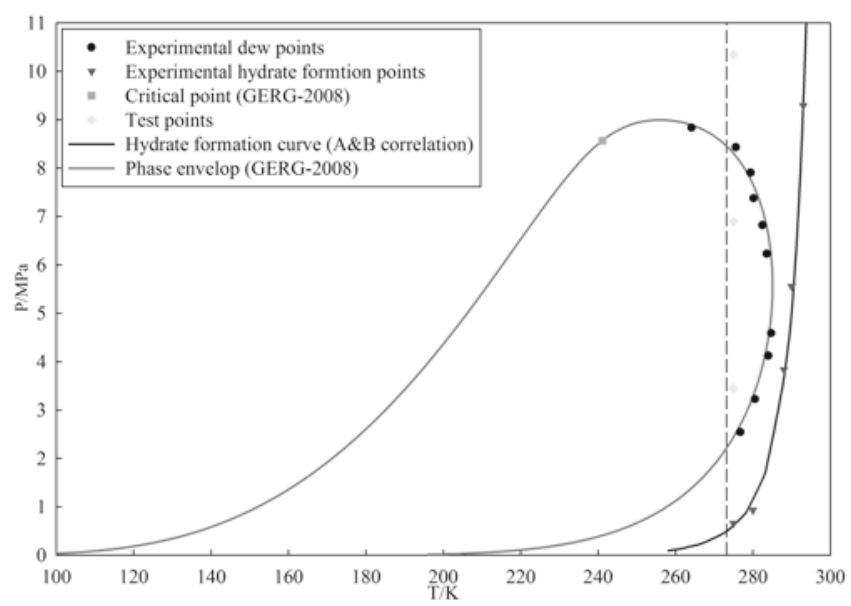

Figure 3. Experimental and predicted phase envelop, critical point [results of GERG-2008 (Kunz and Wagner, 2012)], and pure water hydrate formation curve [result of Ameripour and Barrufet correlation (Ameripour and Barrufet, 2009)] for the natural gas of given composition and test points 
is more realistic. The tests carried on distilled water yielded small amount of gas even at higher pressures, as ice formation preceded hydrate formation.

Figure 4, 5 and 6 show the hydrate promotion capabilities of TSA isomers at three different test points. As it is obvious in these figures the natural gas hydrate storage capacity increases by increasing the pressure as well as the increase in hydrotrope concentration regarding the

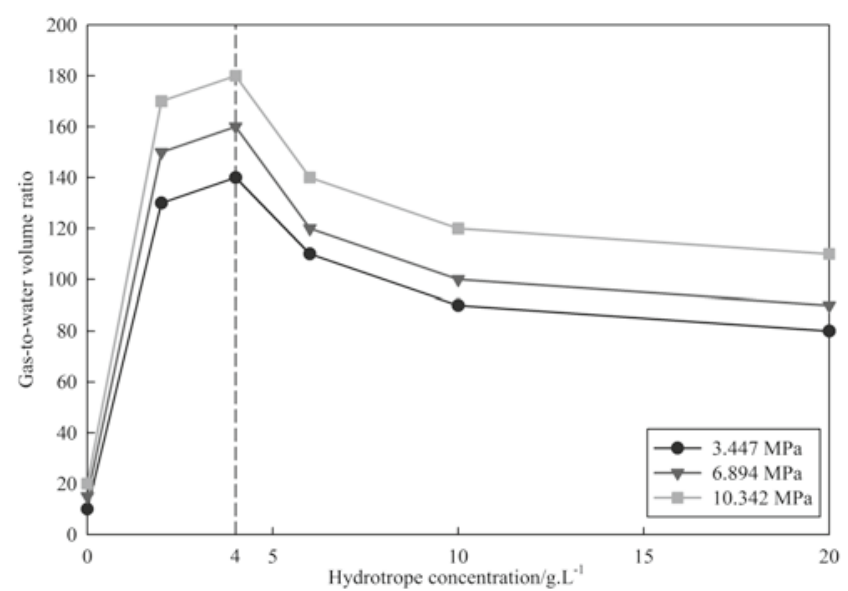

Figure 4. Effect of para-TSA concentration as a promoter on hydrate storage capacity $(\mathrm{T} / 275 \mathrm{~K})$

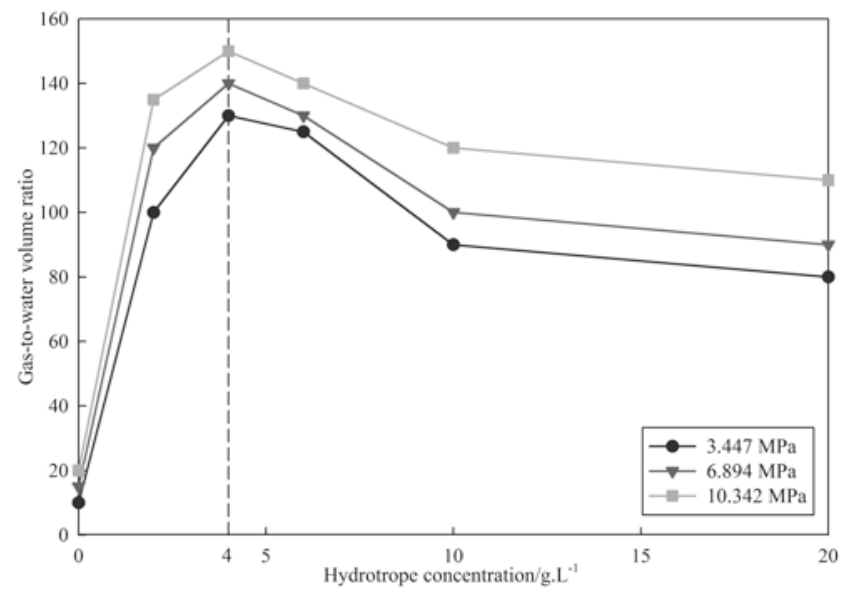

Figure 5. Effect of meta-TSA concentration as a promoter on hydrate storage capacity $(\mathrm{T} / 275 \mathrm{~K})$

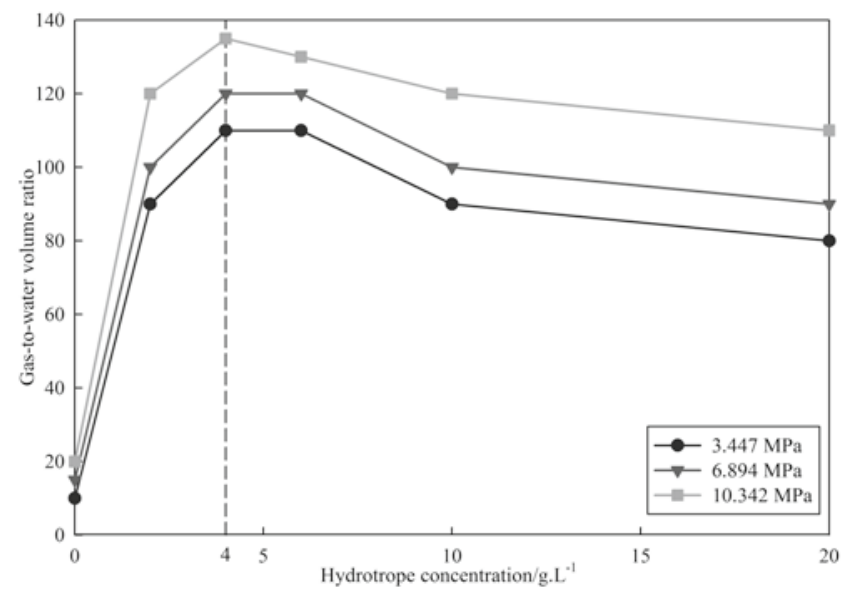

Figure 6. Effect of ortho-TSA concentration as a promoter on hydrate storage capacity $(\mathrm{T} / 275 \mathrm{~K})$ increase in gas-to-water volume ratio. For all of pressure and TSA isomers there is a sharp increasing for storage capacity in hydrotrope concentration of $2 \mathrm{~g} / \mathrm{L}$.

At lower concentration, the surface active molecules are mainly present in the gas water contact and mainly affect the interface properties of the water rather than bulk properties of the solution, so the surface activity of such molecules increases the solubility of gas in water gas contact by higher magnitudes. This enables the hydrate to form in the interface more rapidly, giving shorter induction time. With regard to these figures the optimum additive concentration for hydrate formation at a given pressure, temperature, mixing condition, and the cooling times for all isomers were observed around $4 \mathrm{~g} / \mathrm{L}$ that is the inhibitor effect of higher concentrations on hydrates observed by Rovetto et al. ${ }^{32}$.

Figures 7, 8 and 9 show the hydrate storage capacities promotion of TSA isomers at a certain pressure. It is clear in these figures that the surface activity of para-TSA is $20 \%$ and $35 \%$ more than meta-TSA and ortho-TSA respectively for the concentrations of $4 \mathrm{~g} / \mathrm{L}$. The promoting effect of TSA isomers depends on their arrangement in the surface film of gas water contact and their ability to form a suitable base for nonpolar gas dissolution. As far as para-TSA can fill the water gas contact film therefore, nonpolar gas molecules such as methane and ethane can be dissolved in surface layer

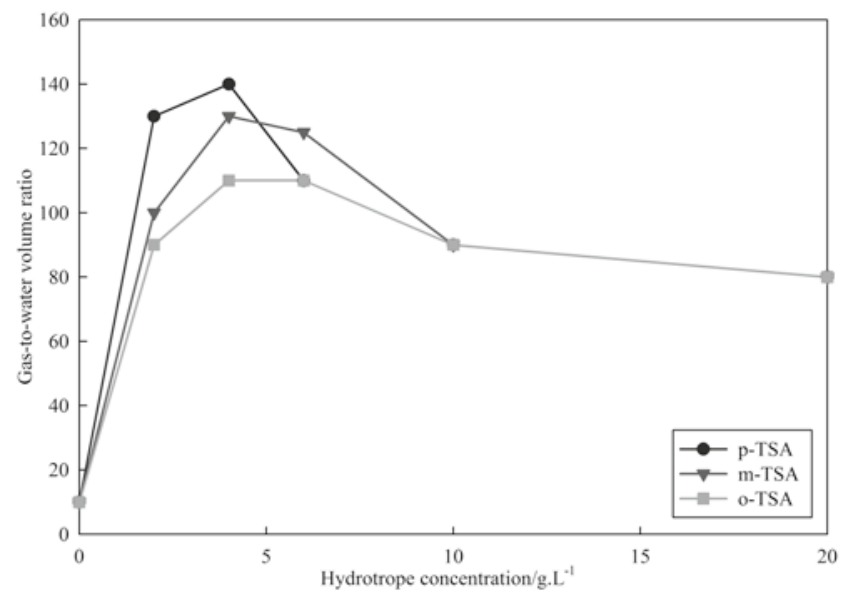

Figure 7. Effects of TSA isomers on the hydrate storage capacity (T/275 K; P/3.447 MPa).

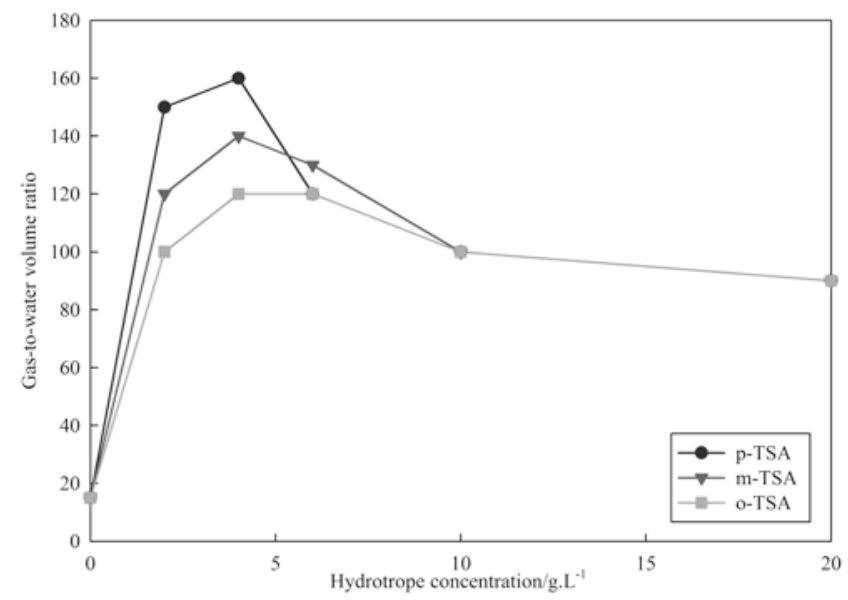

Figure 8. Effects of TSA isomers on the hydrate storage capacity $(\mathrm{T} / 275 \mathrm{~K} ; \mathrm{P} / 6.894 \mathrm{MPa})$ 


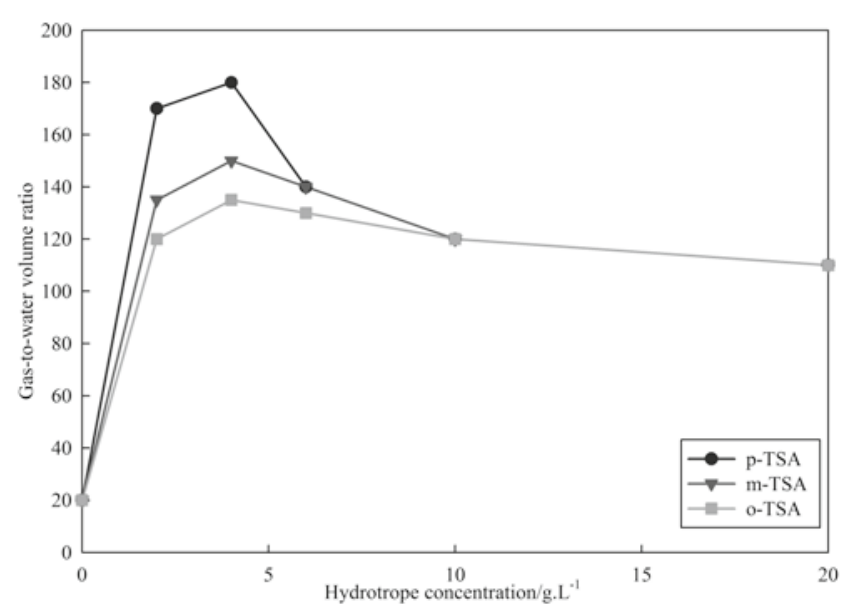

Figure 9. Effects of TSA isomers on the hydrate storage capacity $(\mathrm{T} / 275 \mathrm{~K} ; \mathrm{P} / 10.342 \mathrm{MPa})$

as trapping in its network ${ }^{33}$. Beyond the optimum TSA concentration, the hydrate storage capacity declines and by increasing its amount to $10 \mathrm{~g} / \mathrm{L}$ its promotion capabilities is lower than $2 \mathrm{~g} / \mathrm{L}$.

\section{CONCLUSIONS}

Hydrate promotion capabilities of Toluene Sulfonic Acid (TSA) isomers as a hydrotrope additive was investigated. The optimum additive concentration for hydrate formation at a given pressure and temperature, mixing condition, and cooling times for all isomers was observed to be $4 \mathrm{~g} / \mathrm{L}$. Beyond the optimum TSA concentration, the hydrate formation declined as ice formation reduced the overall gas-to-water volume ratio in the hydrates. The surface activity of para-TSA at the optimum point was $20 \%$ and $35 \%$ more than meta-TSA and ortho-TSA respectively, thus it is suggested to be the best promoter.

\section{LITERATURE CITED}

1. Benesh, M.E. (1942). U.S. Patent No. 2,270,016. Washington, D.C.: U.S. Patent and Trademark Office.

2. Yevi, G.Y. \& Rogers, R.E. (1996). Storage of fuel in hydrates for natural gas vehicles. J. Energy. Resour. Technol. 118(3), 209-213. DOI:10.1115/1.2793864.

3. Zhong, Y. \& Rogers, R.E. (2000). Surfactant effects on gas hydrate formation. Chem. Eng. Sci. 55(19), 4175-4187. DOI: 10.1016/S0009-2509(00)00072-5.

4. Gudmundsson, J.S., Parlaktuna, M. \& Khokhar, A.A. (1994). Storing natural gas as frozen hydrates. SPE Prod. Facil. 9(1), 69-73. DOI: 10.2118/24924-PA.

5. Khokhar, A.A., Gudmundsson, J.S. \& Sloan, E.D. (1998). Gas storage in structure $\mathrm{H}$ hydrates. Fluid. Phase. Equilibr. 150-151, 383392. DOI:10.1016/S0378-3812(98)00338-0.

6. Javanmardi, J., Nasrifar, K., Najibi, S.H. \& Moshfeghian, M. (2005). Economic evaluation of natural gas hydrate as an alternative for natural gas transportation. Appl. Therm. Eng. 25(11-12), 1708-1723. DOI: 10.1016/j.applthermaleng.2004.10.009.

7. Thomas, S. \& Dawe, R.A. (2003). Review of ways to transport natural gas energy from countries which do not need the gas for domestic use. Energy 28(14), 1461-1477. DOI: 10.1016/S0360-5442(03)00124-5.

8. Gudmundsson, J.S. \& Borrehaug, A. (1996). Frozen hydrate for transport of natural gas. In Revelling in Reference: 2nd International Conference on Nature Gas Hydrate, 2-6 June 1996, 415-422, Toulouse, France.
9. Sloan, E.D. \& Koh, C.A. (2008). Clathrate Hydrates of Natural Gases 3rd Edition. CRC Press.

10. Vysniauskas, A. \& Bishnoi, P.R. (1983). A kinetic study of methane hydrate formation. Chem. Eng. Sci. 38(7), 1061-1072. DOI: 10.1016/0009-2509(83)80027-X.

11. Narita, H. \& Uchida, T. (1996). Studies on formation/ dissociation rates of methane hydrates. In Revelling in Reference: 2nd International Conference on Nature Gas Hydrate, 2-6 June 1996, 191-197, Toulouse, France.

12. Kwon, Y.A., Park, J.M., Jeong, K.E., Kim, C.U., Kim, T. W., Chae, H.J., Jeong, S.Y., Yim, J.H., Park, Y.K., Lee, J.D. (2011). Synthesis of anionic multichain type surfactant and its effect on methane gas hydrate formation. J. Ind. Eng. Chem. 17(1), 120-124. DOI:10.1016/j.jiec.2010.12.008.

13. Park, S.S. \& Kim, N.J. (2013). Study on methane hydrate formation using ultrasonic waves. J. Ind. Eng. Chem. 19(5), 1668-1672. DOI: 10.1016/j.jiec.2013.02.004.

14. Kalogerakis, N., Jamaluddin, A.K.M., Dholabhai, P.D. \& Bishnoi, P.R. (1993). Effect of Surfactants on Hydrate Formation Kinetics. In Revelling in Reference: SPE International Symposium on Oilfield Chemistry, 2-5 March 1993, 375-383. New Orleans, Louisiana, USA.

15. Karaaslan, U. \& Parlaktuna, M. (2000). Surfactants as Hydrate Promoters? Energy \& Fuels. 14(5), 1103-1107. DOI: $10.1021 /$ ef000069s.

16. Sun, Z., Ma, R., Fan, S., Guo, K. \& Wang, R. (2004). Investigation on Gas Storage in Methane Hydrate. J. Nat. Gas Chem. 13(2), 107-112.

17. Karaaslan, U. \& Parlaktuna, M. (2001). On the Dissociation of Natural Gas Hydrates from Surfactant Solutions. Energy \& Fuels 15(1), 241-246. DOI:10.1021/ef000060q.

18. Karaaslan, U., Uluneye, E. \& Parlaktuna, M. (2002). Effect of an anionic surfactant on different type of hydrate structures. J. Petrol. Sci. Eng. 35(1-2), 49-57. DOI:10.1016/ S0920-4105(02)00163-8.

19. Imai, S., Mori, Y.H. \& Watanabe, K. (2005). Surfactant effects on hydrate formation in a quiescent gas/liquid system: an experimental study using HFC-32 as a structure-I former. In Revelling in Reference: 5th International Conference on Gas Hydrates, 13-16 June 2005, 347-359. Trondheim, Norway.

20. Heidaryan, E., Salarabadi, A. Moghadasi, J. Dourbash, A. (2010). A new high performance gas hydrate inhibitor. J. Nat. Gas Chem. 19(3), 323-326. DOI: 10.1016/S10039953(09)60060-8.

21. Heidaryan, E., Moghadasi, J. \& Salarabadi, A. (2010). A new and reliable model for predicting methane viscosity at high pressures and high temperatures. J. Nat. Gas Chem. 19 (5), 552-556. DOI: 10.1016/S1003-9953(09)60109-2.

22. Heidaryan, E., Hatami, T., Rahimi, M. \& Moghadasi, J. (2011). Viscosity of pure carbon dioxide at supercritical region: Measurement and correlation approach, J. Supercrit. Fluids. 56(2), 144-151. DOI: 10.1016/j.supflu.2010.12.006.

23. Heidaryan, E. \& Moghadasi, J. (2012). A Laboratory Investigation into Carbon Dioxide Flooding by Focusing on the Viscosity and Swelling Factor Changes, Petrol. Sci. Technol. 30(14), 1441-1452, DOI: 10.1080/10916466.2010.482037.

24. Mandal, A. \& Laik, S. (2008). Effect of the Promoter on Gas Hydrate Formation and Dissociation. Energy \& Fuels 22(4), 2527-2532. DOI:10.1021/ef800240n.

25. Gayet, P., Dicharry, C., Marion, G., Graciaa, A., Lachaise, J. \& Nesterov, A. (2005). Experimental determination of methane hydrate dissociation curve up to $55 \mathrm{MPa}$ by using a small amount of surfactant as hydrate promoter. Chem. Eng. Sci. 60(21),5751-5758. DOI:10.1016/j.ces.2005.04.069.

26. Tohidi, B., Burgass, R.W., Danesh, A., Ostergaard, K.K. \& Todd, A.C. (2000). Improving the Accuracy of Gas Hydrate Dissociation Point Measurements. Ann. N. Y. Acad. Sci. 912 (Gas hydrates: challenges for the future), 924-931. DOI: 10.1111/j.1749-6632.2000.tb06846.x. 
27. Gnanendran, N. \& Amin, R. (2003). The effect of hydrotropes on gas hydrate formation. J. Petrol. Sci. Eng. 40 (1-2): 37-46. DOI: 10.1016/S0920-4105(03)00082-2.

28. Kunz, O. \& Wagner, W. (2012). The GERG-2008 Wide-Range Equation of State for Natural Gases and Other Mixtures: An Expansion of GERG-2004. J. Chem. Eng. Data. 57(11), 3032-3091. DOI: 10.1021/je300655b.

29. Ameripour, S. \& Barrufet, M. (2009). Improved Correlations Predict Hydrate Formation Pressures or Temperatures for Systems With or Without Inhibitors. J. Can. Petrol. Technol. 48(5), 45-50. DOI:10.2118/09-05-45.

30. Makogon, Y.F. (1997). Hydrates of hydrocarbons. PennWell Publishing Co. Tulsa, OK. USA.

31. Giavarini, C. \& Maccioni, F. (2004). Self-preservation at low pressures of methane hydrate with various gas contents. Ind. Eng. Chem. Res. 43(20), 6616-6621. DOI:10.1021/ie040038a.

32. Rovetto, L.J., Strobel, T.A., Koh, C.A. \& Sloan, E.D.Jr. (2006). Is gas hydrate formation thermodynamically promoted by hydrotrope molecules? Fluid. Phase. Equilibr. 247(1-2), 84-89. DOI:10.1016/j.fluid.2006.06.018.

33. Srinivas, V., Rodley, G.A., Ravikumar, K., Robinson, W.T., Turnbull, M.M. \& Balasubramanian, D. (1997). Molecular organisation in hydrotrope assemblies. Langmuir 13(12), 3235-3239. DOI:10.1021/la9609229. 